AperTO - Archivio Istituzionale Open Access dell'Università di Torino

\title{
Carbon Emissions and the Cost of Debt in the Eurozone: the Role of Public Policies, Climate- related Disclosure and Corporate Governance
}

\section{This is a pre print version of the following article:}

Original Citation:

\section{Availability:}

This version is available http://hdl.handle.net/2318/1739646

since 2020-11-11T14:45:42Z

Published version:

DOI:10.1002/bse.2550

Terms of use:

Open Access

Anyone can freely access the full text of works made available as "Open Access". Works made available under a Creative Commons license can be used according to the terms and conditions of said license. Use of all other works requires consent of the right holder (author or publisher) if not exempted from copyright protection by the applicable law. 


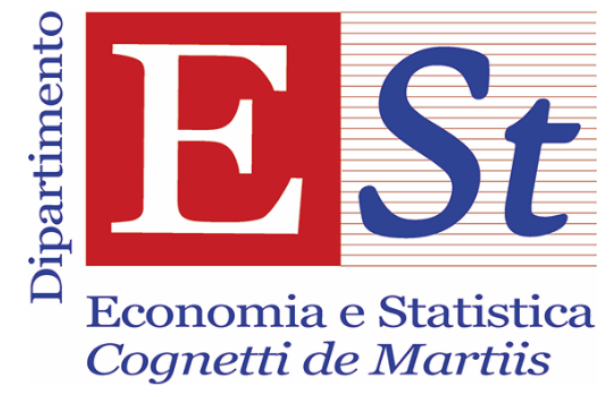

\title{
Working Paper Series
}

$02 / 20$

\section{CARBON EMISSIONS AND THE COST OF DEBT FINANCING: WHAT ROLE FOR POLICY COMMITMENT, FIRM DISCLOSURE AND CORPORATE GOVERNANCE?}

\author{
VERA PALEA and FEDERICO DROGO
}





\title{
Carbon Emissions and the Cost of Debt Financing: What Role for Policy Commitment, Firm Disclosure and Corporate Governance?
}

\author{
Vera Palea* and Federico Drogo \\ Department of Economics and Statistics Cognetti de Martiis \\ University of Torino
}

\begin{abstract}
Over time, investors have become increasingly aware of the risks associated with a transition to a low-carbon economy. This study investigates the association between carbon emissions and the cost of debt financing for a sample of firms from the Eurozone in the period $2010-2018$. Results provide evidence that the risk premium required by lenders increases with carbon emissions. However, while the most polluting sectors were already charged before the Paris Agreement, and not further penalized in the subsequent period, our results indicate that the less polluting sectors started being charged a higher spread for their emissions only in the period after the Agreement. The Paris Agreement appears to be a turning point around which lenders have become aware of the strong commitment taken by policymaker in fighting climate change. Our findings also suggest that increased levels of disclosure on climate-related issues can mitigate corporate carbon risk. On the other hand, results are not compelling when we consider the effect of control mechanisms, such as external verification for emissions, board oversight of carbon risk and the presence of emission reduction targets, on the cost of debt.
\end{abstract}

\section{[THIS VERSION 6 FEBRUARY 2020]}

Keywords: cost of debt, carbon emissions, climate-related disclosure, emission control mechanisms, Paris Agreement, Eurozone

JEL Classification: Go, G3, Mo

*Corresponding author: University of Torino, Department of Economics and Statistics “Cognetti de Martiis", Campus Luigi Einaudi, Lungo Dora Siena 100/A, Torino, Italy; email: vera.palea@unito.it 


\section{Introduction}

In the last few years, financial investors have become increasingly aware of climate change as an emerging risk. According to the World Economic Forum (2020), environmental-related risks - including extreme weather events, failure of climate-change mitigation and adaptation, natural disaster and ecosystem collapse - are the top 5 risks in terms of likelihood and impact. The frequency and severity reached by extreme weather events show that there is substantial support for considering climate change as the gravest threat for economic activities (Pachauri et al., 2014).

Several initiatives have been taken both at an international and national level to tackle global warming and to incentivize economic actors to undertake steps in order to accelerate the transition to a low-carbon economy. The 2015 Paris Agreement (also Agreement hereafter) represents a milestone in such a process. The Paris Agreement was signed in December 2015 and entered into force in November 2016 (UNFCCC, 2019) with the main objective of limiting the average temperature increase to $2 \mathrm{C}^{\circ}$ above the preindustrial level. Ratifying members, among which there is the European Union (EU hereafter), have committed themselves to submit a plan to reduce emissions and to make financial flows consistent with a low-carbon transition.

The EU has always played a leadership role in climate policy (Rayner and Jordan, 2016). Energy and industrial policies are two competences of the EU. Accordingly, the European Commission has incorporated climate change mitigation into its actions, setting a variety of policies to boost investment in infrastructure, such as energy, transport, and communication, along with smart and green manufacturing (European Commission, 2018). Estimates of the needs for such investments in the EU are very significant. The overall infrastructure investment gap is estimated at roughly EUR 403 billion, while investment in research would require an annual investment of EUR 140 billion (European Investment Bank, 2018).

Due to a high average public-sector debt, budgeting consolidation is set to continue at a national level. Thus, an upturn in investments cannot be based only on the public sector or 
classic budgetary stimulus programs. The investment portfolios of financial institutions need to be mobilized and directed toward financing the transition toward a low-emissions economy (European Central Bank, 2018; European Commission, 2013).

With this aim, in 2018 the European Commission published the "Action plan for financing a sustainable growth" (2018; also "Action Plan" hereafter), which is intended to reorient capital flows toward sustainable investments, to help investors manage financial risks stemming from climate change, and to promote transparency and long-termism in investment decisions. With this purpose, the Commission has started working on a taxonomy for sustainable economic activities based on their contribution to climate change mitigation and adaptation. Moreover, the Action Plan considers incorporating climate risk into prudential requirements. A green supporting factor, which gives banks capital relief for their green lending, is currently under discussion at the EU level. Finally, the "Guidelines on reporting climate-related information" (2019) issued by the European Commission provide a list of key-performance indicators, such as greenhouse gas (GHG) emissions, useful to assess a company's exposure to climate change risks.

Central banks and supervision authorities, too, have started analyzing the impacts of climate change on banks' portfolio and the stability of the financial system (NGFS, 2019). Climate change affects the financial system through three main channels. The first involves physical risks, such as floods, landslides, hurricanes, and wildfires, which can destroy relevant fixed assets, thus imposing losses on firms that impair their ability to operate and to repay their debt (NGFS, 2019). Faiella and Natoli (2019), for instance, indicate that over the last years Italian banks have reduced their credit supply to firms in risky areas. The second channel involves transition risk, which refers to the additional costs or devaluation of assets due to changes in the regulation made with the purpose of reducing GHG emissions and adjusting to low-carbon economy (Batten et al., 2018). The introduction of a carbon tax is a typical example of transition risk. Another is the phasing out of coal, already announced by eight EU countries, which is expected to significantly affect coal-based utilities (Euractiv, 2019). The third channel involves liability risk, which is more specific to insurance companies and arises from firms that are damaged from climate change and consequently try to recoup their losses suing other parties or through their insurances. The Netherlands 
Central Bank (Vermeulen et al., 2019), by combining different climate policy responses and energy technologies into four economic scenarios, finds that Dutch insurance might experience losses of around $11 \%$ of their total assets.

This being the context, understanding whether and how higher carbon emissions result in a higher cost of capital is a key issue for all the market players - both capital providers and borrowers - as well as policymakers. To our knowledge, this study is the first to investigate the relationship between the cost of debt financing and corporate carbon risk for a sample of non-financial listed companies from theEurozone for the period 2010-2018. We define carbon risk as any corporate risk related to carbon emissions likely to restrict managers' ability to conduct business (Hoffmann \& Busch, 2008). The focus is on nonfinancial firms, as they represent the backbone of the EU economy, and on loans, which are the main corporate financing source in the EU (European Central Bank, 2018). Importantly, data availability allows us to investigate whether the Paris Agreement has changed the way lenders incorporate carbon risk in their investment decisions.

Complementing prior analyses, our study documents that a positive relationship between carbon risk and the cost of debt holds in the context of the Eurozone. Interestingly, findings indicate that lenders started charging low emitters a higher risk premium for their carbon risk only after the Paris Agreement, when fighting climate change became a stronger commitment at the EU level. Higher emitters, instead, were already charged before the Agreement, and not further penalized in the subsequent period. Taken as a whole, our results suggest that the Paris Agreement represents a turning point after which capital providers started incorporating carbon risk into their lending decisions, both for low and high emitters. As such, they provide support to the European Commission's initiatives aimed at driving the financial system to incorporate climate-related issues into asset allocation. They also show that lenders assess carbon risk on the basis of sector analyses rather than broader industry classifications.

Furthermore, our study indicates that increased levels of climate-related disclosure can mitigate carbon risk. Results, on the other hand, are not compelling when we consider specific control mechanisms of carbon risk such as external validation of carbon emissions, board oversight of carbon risk and the existence of emissions reduction targets. 
The remainder of the paper is as follows. Section 2 reviews the relevant literature and develops the research hypotheses. Section 3 explains the dataset construction and the econometric models, while Section 4 presents the results. Section 5 concludes.

\section{Literature review and hypotheses development}

In the wake of the Paris Agreement and the European Commission's Action Plan, there has been a growing interest in the relationship between corporate carbon risk and investors' decisions. As mentioned above, the adoption of carbon pricing policies represents one important factor that could affect corporate risk, affecting borrowers' future cash flows and, therefore, their ability to repay debts and maintain regular dividend payments. Some studies have also highlighted possible reputational risks for capital providers financing high carbon-risk borrowers, which could lower their capacity to attract future customers and their subsequent ability to generate revenues (e.g., Coulson \& Monsk, 1999; Subramamnian et al., 2015; Thompson, 1998; Thompson and Cowton, 2004).

In general, research documents that capital providers take corporate carbon risk into consideration when they analyze a company's risk profile and define their investment strategies (e.g., Matsumura et al., 2014; Weber, 2012). Carbon risk is usually operationalized as carbon intensity, which is computed as carbon emissions over revenues or total assets (Hoffmann \& Busch, 2008). Some studies have investigated the relationship between carbon intensity and the cost of equity capital. Kim et al. (2015) as well as Trinks et al. (2017), among others, document that the cost of equity increases in carbon risk. Interestingly, results from Trinks et al. (2017) reveal that the relationship between the cost of equity and carbon emissions holds only when both scope 1 and 2 are considered, suggesting that capital providers take both direct and indirect emissions into consideration. Other studies have examined the effect of carbon emissions on the cost of debt. Results generally indicate that higher carbon emitters are considered riskier and thereby pay a higher cost of debt (e.g., Chen \& Gao, 2012; Goss \& Roberts, 2011; Jung et al., 2018; Kleimeier \& Viehs 2018; Weber, 2012). Furthermore, Gianfrate and Peri (2019) document that green bonds are more financially convenient than non-green ones, supporting the view that green projects are considered less risky than the others. 
As a first step for our analysis, we test whether a positive relationship between historical data on carbon emissions and the cost of capital also holds in the Eurozone context. We expect higher polluters to be charged an additional carbon risk premium for the higher uncertainty associated with the transition to a low-carbon economy, which may affect their future cash flows. Accordingly, our first hypothesis (in alternative form) states as follows:

H1: Firms that exhibit a higher carbon risk pay a higher cost of debt.

A consistent regulatory framework may play a key role in driving lending policies. With this purpose, the EU has set over time a variety of policies aimed at reorienting the economy towards low-emissions targets (European Commission, 2018; 2019). Research indeed suggests that after the Paris Agreement banks have started taking into account the risk associated to stranded assets. De Greiff, Delis, and Ongena (2018), for instance, find that since 2015 banks have charged a higher loan spread to fossil fuel firms with higher fossil fuel reserves. Capasso and Gianfrate (2019) show that in the aftermath of the Paris Agreement the exposure to climate change decreases the distance to default for an international sample of companies. Monasterolo and De Angelis (2020) report that the level of systemic risk for low-carbon stock indexes from the US, EU and global financial markets has significantly declined since the Paris Agreement. Coherently, our hypothesis is that after the Paris Agreement investors have increased their awareness of climate change issues, becoming more sensitive to carbon risk. Our hypothesis (in alternative form) states as follows:

H2: The effect of carbon risk on the cost of debt is higher in the years following the Paris Agreement.

Improving corporate disclosure on climate-related risks is one key point of the European Commission's Action Plan (2018). In 2019, the European Commission issued the "nonbinding guidelines on reporting climate-related information", which include guidance on reporting of climate-related information related to business models, key performance indicators, risks and their management. By providing this kind of information, companies can better incorporate carbon risk in their operations, while investors can better assess a company's overall risk (Financial Stability Board, 2016). Understanding whether a relationship exists between increased levels of corporate disclosure on climate-related risks 
and the cost of capital is therefore key for well-informed policymaking.

According to the European Commission (2019), increased levels of disclosure of climate-related risks can provide important benefits to firms, including a potentially lower cost of capital. In the presence of increased levels of disclosure, a lower cost of capital could be ascribed to a reduction, for capital providers, of the uncertainty associated with the investment and thereby to a decrease in the risk premium component associated with information asymmetry.

Lemma et al. (2017) indeed document that voluntary carbon disclosure is associated with a lower overall cost of capital for a sample of South African firms over the period 2010 2015. Kleimeier and Viehs (2018) find similar evidence for an international sample, while Jung et al. (2018) document this relationship for a sample of Australian firms. Gianfrate et al. (2015) however show that the effect of environmental information on the cost of debt varies according to geographical area. In contrast, a few studies point out that increased levels of carbon information come with proprietary costs and could result in revealing information with possible negative repercussions on firms (Guidry \& Patten, 2012; Peters \& Romi, 2014; Verrecchia, 1983).

This being the context, we consider it important to provide further insight into this issue, thus verifying whether a negative relationship between increased levels of disclosure on carbon risks and the cost of debt holds within the specific context of the Eurozone. Consistent with prior research (Jung et al., 2018; Kleimeier \& Viehs, 2018), we measure increased levels of transparency on climate-related issues as the willingness of a firm to respond to the Carbon Disclosure Project's (CDP) questionnaire. CDP is a UK-based not-for-profit organization that targets listed companies with an annual survey concerning their carbon emissions and actions to mitigate climate change risk. The CDP survey is acknowledged worldwide as a leading source of a firm's activity regarding climate change mitigation (Luo et al., 2012; Tang \& Luo, 2014). For this reason, it represents one important data source for the European Commission (2017). Table 1 reports, per each year, the number of firms targeted and responding to the CDP survey - displayed by geographical area - along with the number of firms having verified emissions, board oversight of climate-related issues and emission reduction targets. Our CDP database covers the period 2010-2018 (CDP, 2019).

We assume that increased levels of climate-related disclosure reduce information 
asymmetry and thereby the risk premium component associated with it. Our third hypothesis therefore states (in alternative form) that:

H3: Firms that increase the level of transparency on their carbon risk pay a lower cost of debt.

Emissions data may be prone to measurement errors (Kaspereit \& Lopatta, 2018; Busch et al., 2018). Asking a third party to verify the firm's carbon emission according to an accepted and recognized emissions accounting standard should solve this problem, thus increasing data reliability. For the same reason, the European Commission's guidelines on climate-related information (2019) recommend companies disclosing whether their carbon emissions are externally verified.

Prior research suggests an important role for external certification in accessing both bank and equity financing (Kleimeier \& Viehs, 2018; Trinks et al., 2017). Table 1 shows that the companies responding to the CDP survey have adopted virtuous behaviors over time in this respect. External verification of scope 1 emissions increased from $26 \%$ in 2010 to $56 \%$ in 2018, whereas external verification of scope 2 emissions increased from $22 \%$ in 2010 to $55 \%$ in 2018. In Europe, this trend has been particularly relevant for emission-intensive industries (Green \& Zhou, 2013).

Our third hypothesis aims at verifying whether the existence of a third-party validation for at least scope 1 or scope 2 emissions exerts a mitigating effect on the cost of debt financing in the specific context of the Eurozone. Our hypothesis (in alternative form) therefore states as follows:

H4: Firms whose carbon emissions are not verified by a third party pay a higher cost of debt.

According to the European Commission (2018), corporate governance can significantly contribute to a more sustainable economy, allowing companies to take the strategic steps necessary to manage carbon risk by developing new technologies, adjusting business models toward circular economy and improving environmental performance. Moreover, the presence of adequate board oversight into climate change issues would give evidence of the firm's commitment to address environmental issues, thus improving corporate reputation and legitimacy among stakeholders. The European Commission's non-binding 
guidelines (2019) therefore suggest that companies should disclose whether there is board insight of climate-related issues.

Table 1 shows that, over time, companies responding to the CDP questionnaire increased board insight of climate change issues from $51 \%$ in 2010 to $71 \%$ in 2018. Evidence on the role of corporate board on carbon risk, however, is quite mixed. Some studies suggest a positive association between board environmental orientation and carbon performance (e.g., Moussa, 2018). In contrast, other studies show that boards generally do not fulfill their monitoring roles (e.g., Prado \& Garcia, 2010). Environmental governance mechanisms focus more on avoiding reputational and/or regulatory harm than taking responsible actions (Bansal \& Kistruck 2006; Cho et al. 2012; Neu et al. 1998; Patten 2005; Rodrigue et al., 2013).

Consistent with the European Commission (2018, 2019), we assume that board monitoring can mitigate the corporate carbon risk, thus lowering the cost of debt. Coherently, our hypothesis (in alternative form) states as follows:

H5: Firms that have board oversight of carbon risk pay a lower cost of debt.

So far, our analysis has focused on the relationship between the cost of debt and historical data on carbon emissions. Nonetheless, carbon risk may impact firms to varying degrees depending on the actions that firms are undertaking to confront or even pre-empt the risks and challenges caused by carbon emissions (Labatt \& White, 2007). For this reason, the non-binding guidelines of the European Commission recommend firms disclosing whether they have processes associated with activities that meet the criteria for substantially contributing to mitigation of or adaptation to climate change. Firms with emission reduction targets increased from $38 \%$ in 2010 to $64 \%$ in 2018.

This being the context, we test whether the capital providers consider forward-looking information on carbon emissions as well. In doing this, we assume that Eurozone firms having carbon emission reduction targets in place pay a lower cost of debt. Our last hypothesis therefore states (in alternative form) as follows:

H6: Firms that havecarbon emission reduction targets pay a lower cost of debt.

(INSERT TABLE 1 ABOUT HERE) 


\section{$3 \quad$ Research design}

\subsection{Data and sample construction}

To examine the relationship between the cost of debt financing and corporate carbon risk, we merge data from the CDP and Thomson Reuter's ASSET4 databases. We start from the CDP dataset, which contains the information about external validation of carbon emissions, board insight of climate change issues and carbon emission reduction targets that we need for our analysis.

Table 2 displays the sample selection process. We first select the companies from the Eurozone targeted by the CDP questionnaire. We focus on the Eurozone to avoid problems related to different currencies and monetary policies. We exclude firms from the financial sector, which are subject to specific regulatory requirements. Moreover, their liabilities are different in nature and thereby difficult to compare with other industries (Jung et al., 2018; Pittman \& Fortin, 2004; Rajan \& Zingales, 1995). We collect financial data from the Thompson Reuters database. We use this data provider for carbon emissions as well. In this way, we avoid self-selection bias. In fact, Thompson Reuters' ASSET4 collects emission data from a variety of sources, including companies' reports. As a result, it reports emissions also for firms that are targeted, but not responding to the CDP questionnaire. The CDP database, instead, contains only emission data released by the respondent firms, which may be more virtuous in tackling climate change than the others. Furthermore, our choice allows investigating whether increased levels of disclosure on climate-related issues, operationalized as the willingness to respond to the CDP survey, can mitigate carbon risk. Finally, ASSET4 corrects emissions data in case of ex-post adjustments by reporting companies (Busch et al., 2018), which enhances analysis reliability. Correlation between CDP and ASSET 4 is nonetheless very high, i.e. 95\% for scope 1 and $90 \%$ for scope 2 emissions (Busch et al., 2018). We exclude from our sample firms delisted, failed, or with zero debt. We finally drop observations for which the cost of debt is below the $5 \%$ or above the $95 \%$ percentile. Our final sample consists of 1,469 firm-year observations. 
Table 3 shows our sample distribution over time, divided into firms targeted by the CDP survey, firms responding to the questionnaire, and firms having verified emissions, board oversights, and emission reduction targets. As one can notice, the number of firms targeted by the CDP survey increased by $86 \%$ from 118 in 2010 to 220 in 2018. The response rate varies from $69 \%$ in 2015 to $84 \%$ in 2011 . The response rate is $83 \%$ in 2016 and $80 \%$, both in 2017 and 2018. If compared to the lowest level of 69\% in 2015, this data may suggest that after the Paris Agreement firms consider improving climate-related disclosure as beneficial. The lowest percentage of firms with an external validation for carbon emissions is $74 \%$ for scope 1 and $59 \%$ for scope 2, both in 2010, while the highest percentage is $94 \%$ for scope 1 and $92 \%$ for scope 2, both in 2015. The highest percentage of firms with board oversight (91\%) and emission reduction targets (93\%) is in 2015, whereas the lowest percentage is in 2018 (74\% for board insight and 71\% for emission reduction targets). While the number of firms answering the questionnaire increased in the period following the Paris Agreement, the percentage of firms with external validation for emissions, board oversight and emission reduction targets has decreased compared to 2015. The reason for this could be that firms answering the questionnaire for the first time were not sufficiently skilled in tackling climate change issues compared to those already involved in the program for many years. If this was the case, it would suggest that disclosing climate-related information may provide a good incentive for firms to adopt more virtuous behavior in this respect.

(INSERT TABLE 2 and 3 ABOUT HERE)

Table 4 displays the sample distribution according to industry classification.

\section{(INSERT TABLE 4 ABOUT HERE)}

As Table 4 shows, the industrials group is the most represented, accounting for $29 \%$ of observations. The industrial group includes very different sectors: aerospace and defense, construction and materials, electronic and electrical equipment, general industrials, industrial engineering, industrial support services, and industrial transportation. Since very 
different business models may correspond to very different carbon intensity, we will also account for such heterogeneity in our analysis. Consumer discretionary, which includes $15 \%$ of observations, also comprehends very different sectors such as car producers, media, and leisure goods. The other two relevant groups, which account for $10 \%$ of observations each, are basic materials, including chemicals and industrial materials, metals and mining, and utilities.

Table 5 shows the geographical distribution of our sample. The most represented countries are France and Germany, which together account for $44 \%$ of the observations. Finland, Spain, Italy, and the Netherlands are the other most represented countries, accounting for $46 \%$ of the observations.

\section{(INSERT TABLE 5 ABOUT HERE)}

\subsection{Empirical model and variable definitions}

We use ordinary least square regression to estimate the effect of the carbon risk on the cost of debt.

\subsubsection{Dependent variable: the cost of debt}

The dependent variable in our analysis is the logarithm of the cost of debt. We compute the cost of debt as the ratio between interest expense on the average debt (expressed in basis point). We use the logarithm to linearize the relationship between risk and return (Belsley et al., 1980). Specifically, the cost of debt for firm $i$ in year $t$ is computed as follows:

$$
\operatorname{cod}_{i, t}=\left[\left(\text { interest expense }_{i, t}\right) /\left(\left(\text { tot debt }_{i, t-1}+\text { tot debt }_{i, t}\right) / 2\right)\right]
$$

Interest expense includes interest expense on short- and long-term debt, while total debt is the sum of short- and long-term interest-bearing financial obligations. We truncate the dependent variable at the $5 \%$ and $95 \%$ percentiles of the distribution (Pittman and Fortin, 2004).

\subsubsection{Independent variables}

\subsubsection{Carbon risk}


We use carbon intensity as an indicator of corporate carbon risk (e.g., Hoffmann \& Busch, 2008; Jung, 2018; Lewandowski, 2017). We compute carbon intensity as the ratio between scope 1 and scope 2 emissions and net sales (Jung et al., 2018; Lewandowski, 2017; Capasso \& Gianfrate, 2019). Scope 1 includes direct emissions that originate from plants or sources owned or directly controlled by a company, whereas scope 2 includes emissions originating from the purchase of the electricity needed for a firm's production activities (GHG Protocol, 2019). Considering both scope 1 and scope 2 emissions provides a more comprehensive view of companies' effectiveness in reducing carbon risk. Companies' ability to decrease carbon intensity in the short term, for instance, relies more on scope 2 rather than scope 1 emissions. In fact, buying energy from a sustainable energy producer is easier than investing in emissions reduction technologies, which are likely to be more expensive and require more time to be fully implemented (Busch \& Lewandowski, 2018). We do not instead consider scope 3 emissions, which include all the indirect emissions that originate from a firm's value chain (GHG Protocol, 2019). Scope 3 emissions are difficult to quantify and subject to material errors (Matisoff et al., 2012; Busch et al., 2018). As a result, both the quantity and quality of scope 3 emissions reporting remain highly uncertain (Matisoff et al., 2012; Busch et al., 2018).

We scale carbon emissions by revenues in order to account for different firm size and industry (Hoffmann \& Busch, 2008). Unlike prior research (Jung et al., 2018; Kleimeier \& Viehs, 2018), we test the cost of debt against one year-lagged carbon intensity in order to avoid endogeneity and to increase the robustness of our results with regard to the direction of the relationship between the cost of capital and carbon emissions. By using lagged carbon intensity, we also account for carbon emission data being available with a certain delay. Similarly, firms reap financial benefits from carbon emission mitigation over time (Brzobohaty \& Jansky, 2010; Trump \& Guenther, 2015). We also perform our analysis for a two year-lagged carbon intensity but correlation with the cost of debt is weaker.

\subsubsection{Control variables}

There is no doubt that a close relationship exists between investors' expected returns and financial performance of the firms in which they are investing (e.g., Altman, 2017; Modigliani \& Pogue, 1974) We therefore include companies' financial ratios as control 
variables in our regressions. After a wide review of the literature (e.g., Almamy et al., 2016; Altman et al., 2017; Tian \& Yu, 2017), we select the following financial ratios: operating profit, leverage, working capital ratio and size. Operating profit, computed as the ratio of operating income over net sales, accounts for a firms' profitability. We expect a negative relationship between this variable with the cost of debt as the more profitable firms are, the lower the probability to go bankrupt-(e.g., Tudela \& Young, 2004). Leverage is computed as total debt over total assets and controls for the level of indebtedness (Altman et al., 2017). The working capital ratio, computed as working capital over total asset, accounts for liquidity (Altman et al., 2017). We expect firms that are more indebted, or less liquid, to pay a higher spread on the cost of debt. Finally, we include the logarithm of total assets to proxy for firms' size (Jung et al., 2018; Kleimeier \& Viehs, 2018). Since larger companies are less likely to go bankrupt (i.e., Bernanke et al., 1996, 1999), we expect a negative correlation of this variable with company size (e.g., Jung et al., 2014). To control for monetary policy, we include the yearly average of the 6 months Euribor. Indeed, the cost of debt adjusts in line with the Euribor interest rate variation (Arce at al., 2013; Goss \& Roberts, 2011; Moccero et al., 2014). As for carbon intensity, control variables are lagged by one year in order to avoid endogeneity (Du et al., 2017; Liu et al., 2017). Moreover, lending decisions likely incorporate acompanys financial performance with a certain delay. We finally control for differences in industry and country. Industry classification is based on the Industry Classification Benchmark (ICB) taxonomy. In each regression, standard errors are clustered by firm and year (Petersen, 2009).

\subsection{The econometric models}

The econometric model used to test our first hypothesis is the following:

$$
\begin{gathered}
\ln \left(\operatorname{cod}_{i, t}\right)=\alpha_{0}+\alpha_{1} \text { carbon_int }_{i, t-1}+\sum_{i=1}^{k} \alpha_{k} \text { financial_controls }_{i, t-1}+ \\
\alpha_{3} \text { industry }+\alpha_{4} \text { country }_{i}+\alpha_{5} \text { euribor }_{t-1}+\varepsilon_{i, t}
\end{gathered}
$$

where $\ln \left(\operatorname{cod}_{i, t}\right)$ is the natural logarithm of the cost of debt for firm $i$ in year $t$; carbon_int is the carbon intensity for firm $i$ in year $t$-1; financial_controls is a vector of financial ratios 
for firm $i$ in year $t-1$; industry is the industrial sector for firm $i$; country is the country for firm $i$; and euribor is the euribor in year $t-1$.

The presence of a post-Paris effect is tested with the following model:

$$
\begin{gathered}
\ln \left(\operatorname{cod}_{i, t}\right)=\alpha_{0}+\alpha_{1} \text { carbon_int }_{i, t-1}+\alpha_{2} \text { carbon_int }_{i, t-1} \times \text { post }_{2015}+\alpha_{3} \text { post }_{2015}+ \\
\sum_{i=1}^{k} \alpha_{k} \text { financial }_{\text {controls }_{i, t-1}}+\alpha_{4} \text { industry }_{i}+\alpha_{5} \text { country }_{i}+\alpha_{6} \text { euribor }_{t-1}+\varepsilon_{i, t}
\end{gathered}
$$

where post_2015 is a dummy equal to one after 2015, and zero otherwise, while carbon_int $\mathrm{x}$ post_2015 is an interaction term between the dummy variable and the carbon intensity. The other variables are defined as in model (1).

To test the effect of increased level of disclosure on climate-related issues through answering the CDP questionnaire, we use the following model:

$$
\begin{gathered}
\ln \left(\operatorname{cod}_{i, t}\right)=\alpha_{0}+\alpha_{1} \text { carbon_int }_{i, t-1}+\alpha_{2} \text { carbon_int }_{i, t-1} \times C D P_{i, t-1}+\alpha_{3} C D P_{i, t-1}+ \\
\sum_{i=1}^{k} \alpha_{k} \text { financial_controls }_{i, t-1}+\alpha_{4} \text { industry }_{i}+\alpha_{5} \text { country }_{i}+\alpha_{6} \text { euribor }_{t-1}+\varepsilon_{i, t}
\end{gathered}
$$

where $C D P$ is a dummy is equal to one if the firm answers the CDP questionnaire, and zero otherwise. Carb_int $x$ CDP is the interaction term between the dummy and the carbon intensity. The other variables are defined as in model (1).

The following regression is run in order to test for external verification of emissions:

$$
\begin{gathered}
\ln \left(\operatorname{cod}_{i, t}\right)=\alpha_{0}+\alpha_{1} \text { carbon_int }_{i, t-1}+\alpha_{2} \text { carbon_int }_{i, t-1} \times \text { verified }_{i, t-1}+\alpha_{3} \text { verified }_{i, t-1}+ \\
\sum_{i=1}^{k} \alpha_{k} \text { financial_controls }_{i, t-1}+\alpha_{4} \text { industry }_{i}+\alpha_{5} \text { country }_{i}+\alpha_{6} \text { euribor }_{t-1}+\varepsilon_{i, t}
\end{gathered}
$$

where verified is a dummy variable equal to one if the firm has an external verification of emission either for scope 1 emissions or for scope 2 emissions, and zero otherwise.Carb_int $x$ verified is the interaction term between the dummy and the carbon intensity. The other 
variables are defined as in model (1).

To investigate the role of the effect of board oversight on the cost of debt, the model is:

$$
\begin{aligned}
& \ln \left(\operatorname{cod}_{i, t}\right)=\alpha_{0}+\alpha_{1} \text { carbon_int }_{i, t-1}+\alpha_{2} \text { carbon_int }_{i, t-1} \times \text { board }_{i, t-1}+\alpha_{3} \text { board }_{i, t-1}+ \\
& \sum_{i=1}^{k} \alpha_{k} \text { financial_controls }_{i, t-1}+\alpha_{4} \text { industry }_{i}+\alpha_{5} \text { country }_{i}+\alpha_{6} \text { euribor }_{t-1}+\varepsilon_{i, t}
\end{aligned}
$$

where board is a dummy variable equal to one if the firm has board oversight of climaterelated issues, and zero otherwise. Carb_int $x$ board is the interaction term between the dummy and the carbon intensity. The other variables are defined as in model (1).

We finally run the following regression to investigate the role of carbon emission reduction targets in reducing the cost of debt:

$$
\begin{gathered}
\ln \left(\operatorname{cod}_{i, t}\right)=\alpha_{0}+\alpha_{1} \text { carbon_int }_{i, t-1}+\alpha_{2} \text { carbon_int }_{i, t-1} \times \text { target }_{i, t-1}+\alpha_{3} \text { target }_{i, t-1}+ \\
\sum_{i=1}^{k} \alpha_{k} \text { financial_controls }_{i, t-1}+\alpha_{4} \text { sector }_{i}+\alpha_{5} \text { country }_{i}+\alpha_{6} \text { euribor }_{t-1}+\varepsilon_{i, t}
\end{gathered}
$$

where target is a dummy variable equal to one if the firm has emission reduction targets, and zero otherwise. Carb_int $x$ target is the interaction term between the dummy and the carbon intensity. The other variables are defined as in model (1).

\section{Results ${ }^{1}$}

\subsection{Descriptive statistics and correlation}

Table 6 displays descriptive statistics for the variables included in our regressions. The average value of carbon intensity is 0.41 tonnes of carbon dioxide per EUR 1,000 of

${ }_{1}$ This Section describes and comments on statistical results in compliance with the American Statistical Association Statement on Statistical Significance and P-values (Wasserstein and Lazard, 2016; Wasserstein et al., 2019). Accordingly, we report p-value for regression coefficients, while abandoning the dichotomization of results into "significant" and "not significant". This approach treats statistical results as being much more incomplete than the norm, thus acknowledging that uncertainty exists everywhere in research and that this is exploratory in nature. 
revenues, with a maximum value of 8.76. Data are consistent with other statistics (e.g., Jung et al. 2018). Firm leverage is, on average, $63 \%$ of the total assets, which is also in line with other analyses for EU companies (e.g., ECB 2018). Operating margin is, on average, $10 \%$. $93 \%$ of our sample verify either direct or indirect emissions, while $89 \%$ have boardoversight of climate-related issues, and 90\% set a carbon emission reduction target.

\section{(INSERT TABLE 6 ABOUT HERE)}

Table 7 displays the correlation matrix for the regression variables. As expected, carbon_int is positively correlated with the cost of debt, with a p-value $<0.001$. Lev and the op_margin are also correlated with the cost of debt with the predicted positive and negative sign, respectively, and p-values $<0.001$. The correlation coefficient on the $w c \_t a$ is negative but with a p-value $=0.341$. Contrary to our expectations, the coefficient on size is positive with a $\mathrm{p}$-value $<0.001$. As expected, the existence of an external verification of emissions is negatively correlated with the cost of debt, with a p-value $<0.001$. Both the dummies board and target are negatively correlated with the cost of debt, although with larger pvalues $=0.373$ and $=0.501$ respectively.

Collinearity diagnostics (not reported) show that the variance inflation factors for the explanatory variables are far below critical levels (e.g., Belsley et al. 1980; Greene 2008; Marquardt, 1970).

(INSERT TABLE 7 ABOUT HERE)

\subsection{Multivariate analysis}

\subsubsection{The effect of carbon risk on the cost of debt}

Table 8 displays results from the regression model (1). Column (1) reports results from the regression with the control variables only, whereas column (2) includes carbon intensity. Column (1) and (2) refers to the full sample. 


\section{(INSERT TABLE 8 ABOUT HERE)}

Column (1) shows that, consistent with our prediction, the coefficient on Lev is positive with a pvalue $=0.004$, indicating that the more firms are indebted, the higher the spread on debt. The coefficient on op_marg is negative with a p-value $<0.001$. Contrary to our expectations, the coefficient on $w c \_t a$ is positive with a p-value $=0.040$, which suggests that firms with higher values for this ratio are considered riskier. Indeed, a higher level of working capital on total assets could signal inefficient management of inventories or difficulties in collecting credits. The coefficient on Size is positive but with a high p-value = 0.201. The constant is positive with a p-value $<0.001$ (Jung et al., 2018; Capasso \& Gianfrate, 2019).

The adjusted $\mathrm{R}^{2}$ in column (1) is equal to $25.7 \%$, indicating that a substantial variation in the cost of debt financing is left unexplained by the variables included in the regression. The low adjusted $\mathrm{R}^{2}$ is in line with empirical literature showing that accounting data have lost value-relevance overtime ( $\mathrm{Lev} \& \mathrm{Gu}, 2016$ ) and provides consistent support to the European Commission's claim (2018) that more non-financial disclosure is needed to better understand corporate risk both in absolute and relative terms. Residual analysis (not reported) suggests that results are not affected by omitted variable bias. Regression in column (2) includes carbon intensity. When we introduce the latter, the adjusted $\mathrm{R}^{2}$ increases to $26.7 \%$ indicating that carbon intensity adds to explaining variation in the cost of debt financing. As expected, the coefficient on carbon_int is positive and statistically robust, with a p-value $=0.001$.

We then split the observations and run the regression for the pre- and post-Paris Agreement period, separately. In the post-Paris Agreement period, we include observations from 2016 to 2018. Column (3) shows the results from the regression for the pre-Paris Agreement period, while column (4) reports the results for the post-Paris Agreement period. The coefficients on carbon_int are positive in both the regressions, with a p-value $=0.093$ for the Pre-Paris Agreement and a p-value $<0.001$ for the post-Paris Agreement. A higher magnitude of the coefficient on carbon_int in column (4) suggests increasing lenders' awareness to carbon risk in the aftermath of the Paris Agreement. 
Our results are robust to different model specifications. We also perform a regression by excluding the top polluting sectors (i.e., electricity, and gas, water and multi-utilities) in order to check whether the "carbon intensity effect" on the cost of debt financing is led by the highest emitters. Results (not tabulated) are qualitatively similar to Table 8.

\subsubsection{The Post-Paris Agreement effect: a sectorial analysis}

Table 9 reports results from regression model (2).

\section{(INSERT TABLE 9 ABOUT HERE)}

Column (1) displays the results for the full sample. In this column, the coefficient on carbon_int $x$ post_2015 is positive with a p-value $=0.059$, which suggests an increased lenders' sensitivity to corporate carbon risk in the aftermath of the Paris Agreement. The coefficient on post_2015, instead, is negative, with a p-value $=0.002$, indicating that, on average, the risk premium has decreased since 2015. Such a finding is consistent with wellestablished literature showing that the negative facility rate set by the European Central Bank starting from 2014 has increased risk-taking in the Eurozone (e.g., Heider et al., 2019). Surprisingly, the positive coefficient on the carbon_int is no more statistically robust (p-value $=0.156)$.

To get more insight into this issue, we split the sample into two groups, "high emitters" (also HE hereafter) and "low emitters" (also LE hereafter), according to their sector

carbon intensity. Carbon risk varies significantly across sectors (UNEP, 2006) and may not be captured by the two-digit standard industry classification used in our previous regression. Battiston et al. (2017), for instance, document a similar problem for NACE2 and NAICS classifications.

Table 10 displays our sample distribution by sectors based on a six-digit industry code. Sectors are listed in descending order of carbon intensity median. Our HE group includes sectors having carbon emissions greater than 0.10 tonnes per EUR 1,000 of sales, which are: electricity, gas water and multi-utilities, travel and leisure, chemicals, industrial materials, industrial metals and mining, energy, general industrials, and construction and materials. The Task Force on Climate-related Financial Disclosure (TCFD, 2017) 
considers these sectors particularly vulnerable to climate risks. The HE group represents about $40 \%$ of the sample.

Column (2) and (3) in Table 9 display the results from the regressions for the HE and LE groups, respectively. Interestingly, the coefficient on carbon_int for the HE group is positive with a p-value $=0.049$, whereas the coefficient on carbon_int $x$ post_2015 is positive with a $\mathrm{p}$-value $=0.433$. In contrast, the coefficient on carbon_int for the LE group is negative with a p-value $=0.519$, whereas the coefficient on carbon_int $x$ post_2015 is positive with a $\mathrm{p}$-value $=0.018$. Taken as a whole, these findings suggest that high emitters in the Eurozone were already charged a carbon risk premium before the Paris Agreement, but not further penalized thereafter. On the contrary, low emitters started being charged for their carbon risk only in the aftermath of the Agreement. According to our analysis, the Paris Agreement represents a turning point, in proximity of which lenders have become aware of the strong commitment taken by policymakers in fighting climate change and adopting consistent actions. Accordingly, they have started taking carbon risk into account for both high and low emitters. The regulatory framework therefore appears to have the potential to drive the financial system toward incorporating carbon risk into investment decisions.

Importantly, our findings are robust to alternative criteria for splitting the sample into HE and LE groups, including a classification that is based on firm, rather than sector, carbon intensity. Results are not tabulated for the sake of parsimony.

\section{(INSERT TABLE 10 ABOUT HERE)}

\subsubsection{The roleofdisclosure: reportingthrough the CDP questionnaire}

Table 11 displays the results from the regression model (3), which tests the effect of increased levels of disclosure on the cost of debt. Column (1) shows the results for the full sample, column (2) for the HE group, and column (3) for the LE group. Column (4) and (5) report the results for the HE group in the pre- and post-Paris Agreement period, respectively.

(INSERT TABLE 11 ABOUT HERE) 
As column (1) shows, the coefficient on the interaction term carbon_int $x$ CDP is negative, with a p value $=0.086$, which suggests that increased levels of transparency on carbon risk can contribute to mitigating corporate carbon risk. The coefficient on $C D P$ is positive but not statistically robust $(\mathrm{p}$-value $=0.686)$. When we split the sample into high and low emitters, regression estimates indicate that high emitters disclosing through CDP pay, on average, a lower cost of debt compared to high emitters not disclosing. The coefficient on carbon_int $x$ CDP in column (2) is negative with a p value $=0.034$. In column (3), instead, both the coefficients on carbon_int $x C D P$ and $C D P$ for low emitters are positive, but with large p-values $=0.209$ and 0.298 , respectively. When we further split the observations for the HE group into a pre- and post-Paris Agreement period, the positive effect of disclosing for the HE group appears to hold only in the aftermath of the Paris Agreement. The coefficient on $C D P$ is negative, with a p-value $<0.001$ only in column (5).

Taken as a whole, our analysis suggests that increased levels of climate-related disclosure started playing a role in carbon risk assessment only in the aftermath of the Paris Agreement and for high emitters. Results from Table 11 provide support to findings from Table 9, which indicate that high emitters have not been further penalized for their emissions in the period after the Paris Agreement. In fact, an increased level of disclosure might have contributed to mitigating their carbon risk. Results from Table 11 are also consistent with research showing that since 2015 banks have become aware of the risk of stranded assets for high polluters (e.g., De Greiff, Delis \& Ongena, 2018). Accordingly, banks may have started considering climate-related information in order to better assess corporate carbon risk.

\subsubsection{Third-party verification of emissions and governance}

Table 12 displays results from regression models (4), (5) and (6). For each model, we run the regression for the full sample (column 1), for the HE group (column 2), for the LE group (column 3), for the period before the Paris Agreement (column 4), and for the period after the Paris Agreement (column 5). For the sake of parsimony, we report only the coefficients of interest. 


\section{(INSERT TABLE 12 ABOUT HERE)}

Results from Table 12 do not provide a clear picture of how lenders view external verification of emissions, board oversight of carbon risk and emission reduction targets.

The top panel of the table shows the results for third-party verification. As expected, the coefficient on carbon_int $x$ verified and verified for the full sample is negative. However, the large p-values $=0.194$ and 0.311 , respectively, are not statistically robust to make inference. When we split observations into HE and LE groups, the coefficient on verified for the HE group is still negative and with a p-value $=0.047$, whereas the coefficient on carbon_int $x$ verified is negative, yet with a large $p$-value $=0.617$. For the LE group, the coefficient on verified is also negative but with a p-value $=0.255$, whereas the coefficient on carbon_int $x$ verified becomes positive with a $p$-value $=0.081$. Taken as a whole, thirdparty verifications appear to be important in decreasing the cost of debt for high polluting firms. Surprisingly, they would instead lead to a higher cost of debt for low emitters. When we split the observations into the pre- and post-Paris Agreement period, we find that the coefficient verified is negative, with a p-value $=0.032$ only in the period before the Paris Agreement. In the post-Paris period, the coefficient is positive with a very high p-value of o.364. Further analysis, not reported, indicates that the pre-Paris effect is led by high emitters, which is consistent with low emitters not being charged for carbon risk in the preParis period.

The second panel of the table displays results for board oversight of climate-related issues. The coefficient on board in column (1) is negative with a p-value $=0.043$, which suggests that companies with board oversight pay, on average, a lower spread on the cost of debt. Columns (4) and (5) further indicate that lenders have started considering board oversight only in the aftermath of the Paris Agreement. In column (5), the dummy board has a pvalue $<0.001$, while carbon_int $x$ board a p-value $=0.052$. Both the coefficients are statistically robust. However, while the negative coefficient on board in column (5) suggests a mitigating effect of board oversight on the cost of debt, the positive, and larger, coefficient on carbon_int $x$ board indicates that the sensitivity to carbon risk in the presence of board oversight has increased after the Paris Agreement and results in a higher spread on debt. 
Indeed, the presence of board oversight could signal a firm's higher exposure to climaterelated risk, which requires more control. Results for the LE group and for the pre-Paris period have very large p-values, which do not support robust conclusions.

Findings are also unclear when we test the existence of carbon emission reduction targets. The third panel of the table reports results from the regression model (3). The variables of interest have very large p-values in both the regressions for the full sample and the HE group. In column (3), which refers to the LE group, the coefficient on target has a $\mathrm{p}$-value $=0.064$, while the coefficient on carbon_int $x$ target has a $\mathrm{p}$-value $<0.001$. This occurrence may be consistent with high emitters from the Eurozone already participating in an Emission Trading System (ETS), which set a mandatory cap to their emissions decreasing over time. Under ETS, high emitters are already well monitored and driven by public authorities to low emissions. For instance, during the fourth ETS phase, which will last from 2021 to 2030, the overall number of emission allowances will further decline at an annual rate of $2.2 \%$ compared to the current $1.74 \%$ (European Commission, 2020). In such a context, investors could consider emission reduction targets set at a firm level less relevant, thus ignoring them in credit risk assessment. However, while the negative coefficient on the dummy variable in column (3) indicates that the presence of emission reduction targets mitigates corporate carbon risk for low emitters, the positive coefficient on carbon_int x target suggests that lenders charge a higher spread to borrowers that have a reduction target in place. Again, the presence of emission reduction targets could signal that a certain firm, despite belonging to a low-polluting sector, is highly exposed to carbon risk compared to its peers, and therefore needs to take action. Inconclusive results in this respect have also been found by Kleimeier and Viehs (2018).

As is clear, results from Table 12 are not compelling. From a statistical point of view, this occurrence could be due to the size of our sub-samples. Sample size is an important input to the calculation of confidence limits for measures of effect, and smaller samples can contribute to reducing the statistical test's power (Betensky, 2019). From an economic point of view, findings could be consistent with a context in which carbon risk assessment by lenders as well as the release of climate-related information by firms are something relatively new. Table 8 indeed suggests that lenders have started considering carbon risk 
for all borrowers, both low or high emitters, after the Paris Agreement. Similarly, Table 11 shows that climate-related information has started being incorporated in risk assessment processes only in the aftermath of the Agreement. As a result, it might take some time for investors to incorporate corporate control mechanisms of carbon risk into credit risk assessment practices. Further evidence is needed in this respect.

\section{Conclusion}

This study analyses the relationship between corporate carbon risk and the cost of debt for a sample of listed firms from the Eurozone for the 2010-2018 period. The geographic area under analysis is particularly interesting, as the EU has set sustainable development as one of its main objectives (Lisbon Treaty, 2007). Since the Paris Agreement, the European Commission has taken an increasing number of actions to rapidly adjust the economic system to low-emission targets. In 2018, the European Commission launched the Action Plan for financing sustainable growth, which is intended to reorient financial market participants toward sustainable investments and to help them better assess climate risk. In 2019, it released updated guidelines and recommendations on climate-related disclosures, which should provide investors with better information on corporate carbon risk. The period covered by our analysis allows the examination of the effects of carbon emissions on lending policies in the period immediately subsequent to the Paris Agreement.

Our results provide evidence that higher carbon emissions are associated with a higher cost of debt financing. However, while high emitters were already charged a carbon risk premium before the Paris Agreement, low emitters started being charged a higher spread only in the subsequent period. According to our analysis, in the period surrounding the Paris Agreement, lenders changed the way they consider corporate carbon risk. It is likely that lenders have become aware of the strong commitment taken by policymakers in fighting climate change and adopting consistent actions, thus starting to price carbon risk for all the borrowers, despite being either high or low emitters.

When we investigate the role of disclosure, results indicate that increased levels of climaterelated disclosure exert a mitigating effect on the cost of debt. Such evidence, however, holds only for high emitters and in the period after the Paris Agreement, which can explain why 
high emitters appear not to have been further penalized in the aftermath of the Agreement. In fact, increased levels of disclosure might have reduced the risk premium component associated to information asymmetry.

Our results, instead, are not compelling as far as investors view external validation of emissions, board oversight of climate-related issues and the existence of emission reduction targets. Further evidence is needed in this respect.

To conclude, this study provides robust evidence that a strong policy commitment to keep global warming under control can lead investors to consider corporate carbon risk in their investment decisions. As such, our analysis supports the proactivity of the European Commission on these issues. With the same aim, further research into the relationship between corporate carbon risk and probability of default would be useful. If a robust relationship could be empirically proved, then regulators should differentiate between high and low emitters for capital requirement purposes so as to further incentivize financial institutions' investments in the transition to a low carbon economy. 


\section{References}

Almamy, J., Aston, J., and Ngwa, L. N. (2016). An evaluation of Altman's z-score using cash flow ratio to predict corporate failure amid the recent financial crisis: Evidence from the UK. Journalof Corporate Finance, 36:278- 285.

Altman, E. I., Iwanicz-Drozdowska, M., Laitinen, E. K., and Suvas, A. (2017). Financial distress prediction in an international context: A review and empirical analysis of Altman's Z-score model. Journal of International Financial Management \& Accounting, 28(2):131-171.

Arce, O., Mayordomo, S., \& Peña, J. I. (2013). Credit-risk valuation in the sovereign CDS and bonds markets: Evidence from the euro area crisis. Journal of International Money and Finance, 35, 124-145.

Banca d'Italia (2019). The Bank of Italy values sustainability in its financial investments.

Bansal, P. and Kistruck, G. (2006). Seeing is (not) believing: Managing the impression of the firm's commitment to the natural environment. Journal of Business Ethics, 67(2):165-180.

Batten, S. et al. (2018). Climate change and the macro-economy: a critical review. Technical report, Bank of England.

Battiston, S., Mandel, A., Monasterolo, I., Schütze, F., and Visentin, G. (2017). A climate stress-test of the financial system. Nature Climate Change, 7(4):283.

Bauer, R. and Hann, D. (2010). Corporate environmental management and credit risk. Available at SSRN.

Belsley, D. A., Kuh, E. and Welsch, R. E. (1980). Regression diagnostics: Identifying influential data and sources of collinearity. Wiley series in probability and statistics.

Bernanke B., Gertler M. \& Gilchrist S. (1996). The Financial Accelerator and the Flight to Quality. The Review of Economics and Statistics, 78 (1), 1-15.

Bernanke B., Gertler M. \& Gilchrist S. (1999). The Financial Accelerator in Quantitative Business Cycle Framework. In: Handbook of Macroeconomics, North-Holland, Amsterdam, 1341-1393.

Betensky, R. (2019), “The p-Value Requires Context, Not a Threshold,” The American Statistician, 73 . 
Botosan, C. A. (1997). Disclosure level and the cost of equity capital. Ac- counting review, pages 323-349.

Brooks, C. and Oikonomou, I. (2018). The effects of environmental, social and governance disclosures and performance on firm value: A review of the literature in accounting and finance. The British Accounting Review, 50(1):1-15.

Busch, T. (2010). Corporate carbon performance indicators revisited. Journal of Industrial Ecology, 14(3):374-377.

Busch, T., Johnson, M., Pioch, T., Kopp, M. (2018). Consistency of corporate carbon emission data. University of Hamburg/WWF Deutschland, Hamburg

Busch, T. and Lewandowski, S. (2018). Corporate carbon and financial performance: A meta-analysis. Journal of Industrial Ecology, 22(4):745- 759.

Capasso, G. and Gianfrate, G. (2019). Climate change and credit risk. CDP (2019). Cdp media factsheet. Technical report, CDP.

Chen, L. H. and Silva Gao, L. (2012). The pricing of climate risk. Journal of Financial and Economic Practice, Vol12 (2), Spring, pages 115-131.

Cho, C. H., Freedman, M. and Patten, D. M. (2012). Corporate disclosure of environmental capital expenditures: A test of alternative theories. Accounting, Auditing and Accountability,

25(3):486-507.

Clark, G. L., Feiner, A., and Viehs, M. (2015). From the stockholder to the stakeholder: How sustainability can drive financial outperformance. Available at SSRN 2508281.

Coulson, A. B. and Monks, V. (1999). Corporate environmental performance considerations within bank lending decisions. Corporate Social-Responsibility and Environmental Management, 6(1):1-10.

Delis, M., De Greiff, K., and Ongena, S. (2018). Being stranded on the carbon bubble? Climate policy risk and the pricing of bank loans. SFI Research Paper, (8-10).

Du, X., Weng, J., Zeng, Q., Chang, Y., and Pei, H. (2017). Do lenders applaud corporate environmental performance? Evidence from chinese private- owned firms. Journal of Business Ethics, 143(1):179-207.

European Central Bank (2019). Climate change and financial stability. Financial Stability 


\section{Review, 1.}

European Commission (2013). Green paper: Long-term financing of the European economy.

European Commission (2017). Guidelines on non-financial reporting - Methodology for reporting non-financial information.

European Commission (2018). Action Plan: Financing Sustainable Growth.

European Commission (2019). Guidelines on non-financial reporting: Supplement on reporting climate-related information.

European Commission (2020). Emission Trading System - Revision for Phase 4.

European Central Bank (2018). Preserving monetary accomodation in times of normalisation. Speech by Mr Peter Praet. Frankfurt am Main.

Eccles, R. G., Serafeim, G., and Krzus, M. P. (2011). Market interest in nonfinancial information. Journal of Applied Corporate Finance, 23(4):113- 127.

European Investment Bank (2018). Economic Investment Report 2018/2019: Retooling Europe's economy. Technical report.

Euractiv (2019). Only eight EU contries plan to phase out coal by 2030.

Faiella, I. and Natoli, F. (2019). Climate change and bank lending: the case of flood risk in italy.

Fatica, S., Panzica, R., Rancan, M., et al. (2019). The pricing of green bonds: are financial institutions special? Technical report.

Forster, M. R. and Sober, E. (1994). How to tell when simpler, more unified, or less ad hoc theories will provide more accurate predictions. British Journal for the Philosophy of Science, 45(1):1-35.

FSB (2016). Recommendations of the task force on climate-related financial disclosures. Financial Stability Board, Basel, Switzerland.

Gebhardt, W. R., Lee, C. M., and Swaminathan, B. (2001). Toward an implied cost of capital. Journal of accounting research, 39(1):135-176.

Gianfrate, G. and Peri, M. (2019). The green advantage: Exploring the convenience of issuing green bonds. Journal of Cleaner Production, 219:127- 135.

Gianfrate, G., Schoenmaker, D., and Wasama, S. (2015). Cost of capital and 
sustainability: a literature review. Rotterdam School of Management, Erasmus University.

Goss, A. and Roberts, G. S. (2011). The impact of corporate social responsibility on the cost of bank loans. Journal of Banking \& Finance, 35(7):1794- 1810.

Green, W. and Zhou, S. (2013). An international examination of assurance practices on carbon emissions disclosures. Australian Accounting Review, 23(1):54-66.

Greene, W. H. (2008). Econometric analysis (Sixth Edition). Pearson Prentice Hall.

Guidry, R. P. and Patten, D. M. (2012). Voluntary disclosure theory and financial control variables: An assessment of recent environmental disclosure research. Accounting Forum, 36(2):81-90. https://doi.org/10.1016/j.accfor.2012.03.002

Hahn, R., Reimsbach, D., and Schiemann, F. (2015). Organizations, climate change, and transparency: Reviewing the literature on carbon disclosure. Organization \& Environment, 28(1):80-102.

Heider, F., Saidi, F., and Schepens, G. (2019). Life below zero: Bank lending under negative policy rates. The Review of Financial Studies, 32(10):3728-3761.

Hoffmann, V. H. and Busch, T. (2008). Corporate carbon performance indicators: Carbon intensity, dependency, exposure, and risk. Journal of Industrial Ecology, 12(4):505520.

Jefferys, W. and Berger, J. (1992). Ockham's razor and Bayesian analysis. American Scientist, 80:64-72.

Jung, J., Herbohn, K., and Clarkson, P.(2018). Carbon risk, carbon risk aware- ness and the cost of debt financing. Journal of Business Ethics, 150(4):1151- 1171.

Kaspereit, T. and Lopatta, K. (2018). Detecting carbon emission disclosure management. Available at SSRN 3095495.

Kim, Y.-B., An, H. T., and Kim, J. D. (2015). The effect of carbon risk on the cost of equity capital. Journal of Cleaner Production, 93:279-287.

Kleimeier, S. and Viehs, M. (2018). Carbon disclosure, emission levels, and the cost of debt. Emission Levels, and the Cost of Debt (January 7, 2018).

La Rosa, F., Liberatore, G., Mazzi, F., and Terzani, S. (2018). The impact of corporate social performance on the cost of debt and access to debt financing for listed european non- 
financial firms. European Management Journal, 36(4):519-529.

Labatt, S. and White, R. R. (2007). Carbon finance: the financial implications of climate change. John Wiley \& sons.

Lambert, R., Leuz, C., and Verrecchia, R. E. (2007). Accounting information, disclosure, and the cost of capital. Journal of accounting research, 45(2):385- 420.

Lemma, T. T., Feedman, M., Mlilo, M. and Park, J.D. (2017). Corporate carbon risk, voluntary disclosure, and cost of capital: South African evidence. Business Strategy and the Environment, 28(1): 111-126.

Leuz, C. and Wysocki, P. D. (2016). The economics of disclosure and financial reporting regulation: Evidence and suggestions for future research. Journal of Accounting Research, 54(2):525-622.

Lev, B. and Gu, F. (2016). The end of accounting and the path forward for investors and managers. John Wiley \& Sons.

Liu, Y., Zhou, X., Yang, J., and Hoepner, A. G. (2017). Corporate carbon emissions and financial performance: Does carbon disclosure mediate the relationship in the UK? Available at SSRN 2941123.

Luo, L., Lan, Y.-C. and Tang, Q. (2012). Corporate incentives to disclose carbon information: Evidence from the CDP Global 500 report. Journal of International Financial Management \& Accounting, 23(2):93-120.

Luo, L. and Tang, Q. (2014). Does voluntary carbon disclosure reflect un- derlying carbon performance? Journal of Contemporary Accounting \& Economics, 10(3):191-205.

Maaloul, A. (2018). The effect of greenhouse gas emissions on cost of debt: Evidence from canadian firms. Corporate Social Responsibility and Environ- mental Management, 25(6):1407-1415.

Marquardt, D. W. (1970). Generalized inverses, ridge regression, biased linear estimation, and nonlinear estimation. Technometrics, 12(3):605-607.

Matisoff, D. C., Noonan, D. S. and O'Brien, J. J. (2013). Convergence in environmental reporting: assessing the carbon disclosure project. Business Strategy and the Environment, 22:285-305.

Moccero, D. N., Pariès, M. D., \& Maurin, L. (2014). Financial conditions index and 
identification of credit supply shocks for the euro area. International finance, 17(3), 297321.

Monasterolo, I., \& De Angelis, L. (2020). Blind to carbon risk? An analysis of stock market reaction to the Paris Agreement. Ecological Economics, 170, 106571.

Moussa, T., Allam, A., Elbanna, S. and Bani-Mustafa, A. (2018). Can board environmental orientation improve US firms' carbon performance? The mediating role of carbon strategy. Business Strategy and the Environment, 29(1): 72-86.

Neu, D., Warsame, H. and Predwell, K. (1998). Managing public impressions: Environmental disclosures in annual reports. Accounting, Organizations and Society, 23:265-282.

Pachauri, R. K., Allen, M. R., Barros, V. R., Broome, J., Cramer, W., Christ, R., Church, J. A., Clarke, L., Dahe, Q., Dasgupta, P., et al. (2014). Climate change 2014: synthesis report. Contribution of Working Groups I, II and III to the fifth assessment report of the Intergovernmental Panel on Climate Change. IPCC.

Patten, D. M. (2005). The accuracy of financial report projections of future environmental capital expenditures: A research note. Accounting, Organizations and Society, 30(5):457468.

Peters, G. and Romi, A. (2014). Does the voluntary adoption of corporate governance mechanisms improve environmental risk disclosures? Evidence from greenhouse gas emission accounting. Journal of Business Ethics, 125(4):637-666.

Pittman, J. A. and Fortin, S. (2004). Auditor choice and the cost of debt capital for newly public firms. Journal of accounting and economics, 37(1):113- 136.

Rajan, R. and Zingales, L. (1995). What do we know about capital structure: Evidence from G-7 countries. Journal of Finance, 50(5):1421-1460.

Rayner, T. and Jordan, A. (2016). Climate change policy in the European Union. In Oxford Research Encyclopedia of Climate Science.

Rodrigue, M., Magnan, M. and Cho, C. H. (2013). Is environmental governance substantive or symbolic? An empirical investigation. Journal of Business Ethics, 114(1):107-129.

Schwarz, G. (1978). Estimating the dimension of a model. Annals of Statistics, 6(2):461465 . 
S\&P (2019). The role of environmental, social, and governance credit factors in our ratings analysis.

Subramaniam, N., Wahyuni, D., Cooper, B. J., Leung, P. and Wines, G. (2015). Integration of carbon risks and opportunities in enterprise risk management systems: Evidence from Australian firms. Journal of Cleaner Production, 96(0):407-417.

Tang, Q. and Luo, L. (2014). Carbon management systems and carbon mitigation. Australian Accounting Review, 24(1):84-98.

Thompson, P. (1998). Bank lending and the environment: Policies and opportunities. International Journal of Bank Marketing, 16(6):243-252.

Thompson, P. and Cowton, C. J. (2004). Bringing the environment into bank lending: Implications for environmental reporting. The British Accounting Review, 36(2):197218.

Tian, S. and Yu, Y. (2017). Financial ratios and bankruptcy predictions: An international evidence. International Review of Economics \& Finance, 51:510-526.

Trinks, A., Mulder, M., and Scholtens, B. (2017). Greenhouse gas emissions intensity and the cost of capital. Technical report, University of Groningen.

Tudela, Merxe and Young, Garry, A Merton-Model Approach to Assessing the Default Risk of UK Public Companies (June 2003). Bank of England Working Paper Series No. 194.

UNEP, F. (2006). Global climate change: Risk to bank loans.

UNFCCC (2019). Paris Agreement - status of ratification.

Vermeulen, R., Schets, E., Lohuis, M., Ko“lbl, B., Jansen, D.-J., and Heeringa,

Verrecchia, R. E. (1983). Discretionary disclosure. Journal of Accounting and Economics, 5(1):179-194.

Vermeulen, Robert and Schets, Edo and Lohuis, Melanie and Kölbl, Barbara and Jansen, David-Jan and Heeringa, Willem, The Heat Is on: A Framework for Measuring Financial Stress Under Disruptive Energy Transition Scenarios (February 25, 2019). De Nederlandsche Bank Working Paper No. 625 (2019).

Wasserstein Ronald L. and Nicole A. Lazar (2016). The ASA Statement on $p$-Values: Context, Process, and Purpose, The American Statistician, 70:2, 129-133. 
Wasserstein Ronald L., Allen L. Schirm and Nicole A. Lazar (2019). Moving to a World Beyond " $p<0.05$ ", The American Statistician, 73:sup1, 1-19, World Economic Forum (2020). Global risks report. Technical report. 
Table 1- CDP Database 2010-2018 - Firm distribution per year

\begin{tabular}{|c|c|c|c|c|c|c|c|c|c|c|}
\hline & 2010 & 2011 & 2012 & 2013 & 2014 & 2015 & 2016 & 2017 & 2018 & Total \\
\hline Firms targeted by CDP & 6,221 & 6,557 & 7,071 & 7,455 & 7,167 & 6,302 & 5,815 & 6,028 & 6,083 & 58,699 \\
\hline Asia & 2,013 & 2,185 & 2,203 & 2,287 & 2,495 & 2,084 & 1,937 & 2,007 & 2,030 & 19,241 \\
\hline America & 1,757 & 1,336 & 1,685 & 1,816 & 1,734 & 1,337 & 1,275 & 1,485 & 1,454 & 13,879 \\
\hline Africa & 131 & 150 & 155 & 162 & 134 & 130 & 97 & 122 & 123 & 1,204 \\
\hline Oceania & 263 & 282 & 306 & 321 & 291 & 271 & 263 & 264 & 269 & 2,530 \\
\hline Europe & 2,056 & 2,604 & 2,721 & 2,869 & 2,513 & 2,480 & 2,243 & 2,149 & 2,207 & 21,842 \\
\hline Firms answering to CDP & 2,434 & 2,464 & 2,534 & 2,700 & 2,575 & 2,776 & 2,506 & 2,756 & 2,372 & 23,117 \\
\hline Asia & 525 & 562 & 594 & 618 & 619 & 683 & 649 & 748 & 641 & 5,639 \\
\hline America & 770 & 656 & 688 & 746 & 726 & 791 & 683 & 776 & 703 & 6,539 \\
\hline Africa & 70 & 84 & 86 & 89 & 86 & 89 & 69 & 84 & 67 & 724 \\
\hline Oceania & 111 & 115 & 119 & 122 & 102 & 117 & 103 & 108 & 89 & 986 \\
\hline Europe & 958 & 1,047 & 1,047 & 1,125 & 1,042 & 1,096 & 1,002 & 1,039 & 872 & 9,228 \\
\hline Firms with scope 1 emissions externally verified & 630 & 805 & 995 & 1,051 & 1,139 & 1,217 & 1,193 & 1,358 & 1,333 & 9,721 \\
\hline Firms with scope 2 emissions externally verified & 546 & 729 & 915 & 1,001 & 1,091 & 1,174 & 1,152 & 1,316 & 1,297 & 9,221 \\
\hline Firms with board oversight of climate-related issues & 1,238 & 1,137 & 1,286 & 1,359 & 1,442 & 1,538 & 1,472 & 1,737 & 1,686 & 12,895 \\
\hline Firms with emission reduction targets & 927 & 1,030 & 1,198 & 1,280 & 1,370 & 1,456 & 1,410 & 1,662 & 1,529 & 11,862 \\
\hline
\end{tabular}


Table 2 - Sample selection process

Firm-year observations

Firm-year observations for the Eurozone

11,253

- Financial institutions

$(1,296)$

- Missing data (carbon intensity or control variables)

$(8,132)$

- Failed or delisted companies

- Firms with zero debt

- Outliers (trimmed 5-95\%)

Final sample

1,469 


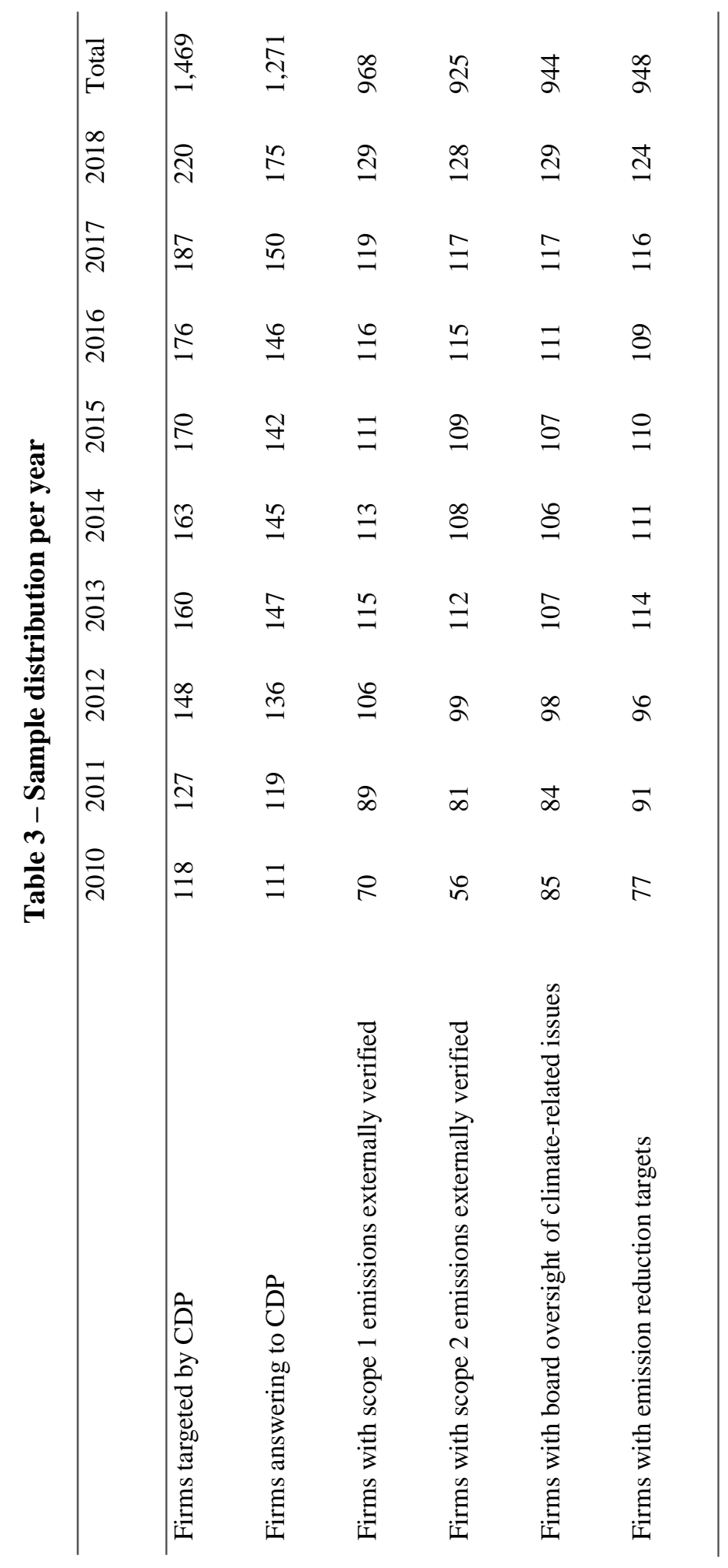


Table 4 - Sample distribution by ICB Industry (firm-year observations)

\begin{tabular}{lccc}
\hline & Frequency & Percentage & Cumulated \\
\hline Basic Materials & 149 & 10.14 & 10.14 \\
Consumer Discretionary & 231 & 15.72 & 25.87 \\
Consumer Staples & 110 & 7.49 & 33.36 \\
Energy & 98 & 6.67 & 40.03 \\
Health Care & 84 & 5.72 & 45.75 \\
Industrials & 429 & 29.20 & 74.95 \\
Technology & 91 & 6.19 & 81.14 \\
Telecommunications & 127 & 8.65 & 8.79 \\
Utilities & 150 & 10.21 & \\
Total & & & \\
\hline
\end{tabular}


Table 5 - Sample distribution by country (firm-year observations)

\begin{tabular}{cccc}
\hline & Frequency & Percentage & Cumulated \\
\hline Austria & 40 & 2.72 & 2.72 \\
Belgium & 44 & 3.00 & 5.72 \\
Finland & 161 & 10.96 & 16.68 \\
France & 355 & 24.17 & 40.84 \\
Germany & 295 & 20.08 & 60.93 \\
Greece & 22 & 1.50 & 62.42 \\
Ireland & 62 & 4.22 & 66.64 \\
Italy & 136 & 9.26 & 75.90 \\
Luxembourg & 24 & 1.63 & 77.54 \\
Netherlands & 134 & 9.12 & 86.66 \\
Portugal & 38 & 2.59 & 89.24 \\
Spain & 158 & 10.76 & 100 \\
Total & 1,469 & 100 & \\
\hline
\end{tabular}


Table 6 - Sample descriptive statistics

\begin{tabular}{ccccccccc}
\hline Variable & Count & Mean & $\mathrm{p} 25$ & Median & $\mathrm{p} 75$ & SD & Minimum & Maximum \\
\hline Ln(cod) & 1,469 & 5.95 & 5.71 & 6.00 & 6.24 & 0.40 & 4.78 & 6.85 \\
Carbon_int & 1,469 & 0.41 & 0.02 & 0.06 & 0.37 & 1.00 & 0.00 & 8.76 \\
Lev & 1,469 & 0.63 & 0.53 & 0.63 & 0.72 & 0.15 & 0.17 & 1.44 \\
Op_marg & 1,469 & 0.10 & 0.04 & 0.09 & 0.14 & 0.1 & -0.41 & 0.54 \\
Wc_ta & 1,469 & 0.07 & -0.02 & 0.05 & 0.14 & 0.13 & -0.45 & 0.51 \\
Size & 1,469 & 16.21 & 15.30 & 16.08 & 17.15 & 1.29 & 13.09 & 19.81 \\
Euribor & 1,469 & 0.48 & -0.16 & 0.31 & 1.08 & 0.64 & -0.26 & 1.64 \\
CDP & 1,206 & 0.88 & - & - & - & 0.33 & 0.00 & 1.00 \\
Verified & 1,044 & 0.93 & - & - & - & 0.26 & 0.00 & 1.00 \\
Board & 1,059 & 0.89 & - & - & - & 0.31 & 0.00 & 1.00 \\
Target & 1,053 & 0.90 & - & - & - & 0.30 & 0.00 & 1.00
\end{tabular}

List of Variables: $\operatorname{Ln}(\mathrm{cod})$ is the dependent variable defined as the natural logarithm of the ratio between interest expense on debt and average total debt; Carbon_int is the carbon intensity computed as the ratio between scope 1 and scope 2 emissions over revenues. Lev is the leverage defined as total liabilities over total assets. Op_marg is the operative margin defined as the ratio between operating income and revenues. $W c_{-} t a$ is the ratio of working capital over total assets. Size is the natural logarithm of total assets. Euribor is the yearly average of the 6-months Euribor. CDP is a dummy variable equal to 1 if the firms answers the CDP questionnaire. Verified is a dummy variable equal to 1 if the firm has either scope 1 or scope 2 emissions externally verified. Board is a dummy variable equal to 1 if the firm has board oversight of climate-related issues. Target is a dummy variable equal to 1 if the firm has an emissions reduction target. 


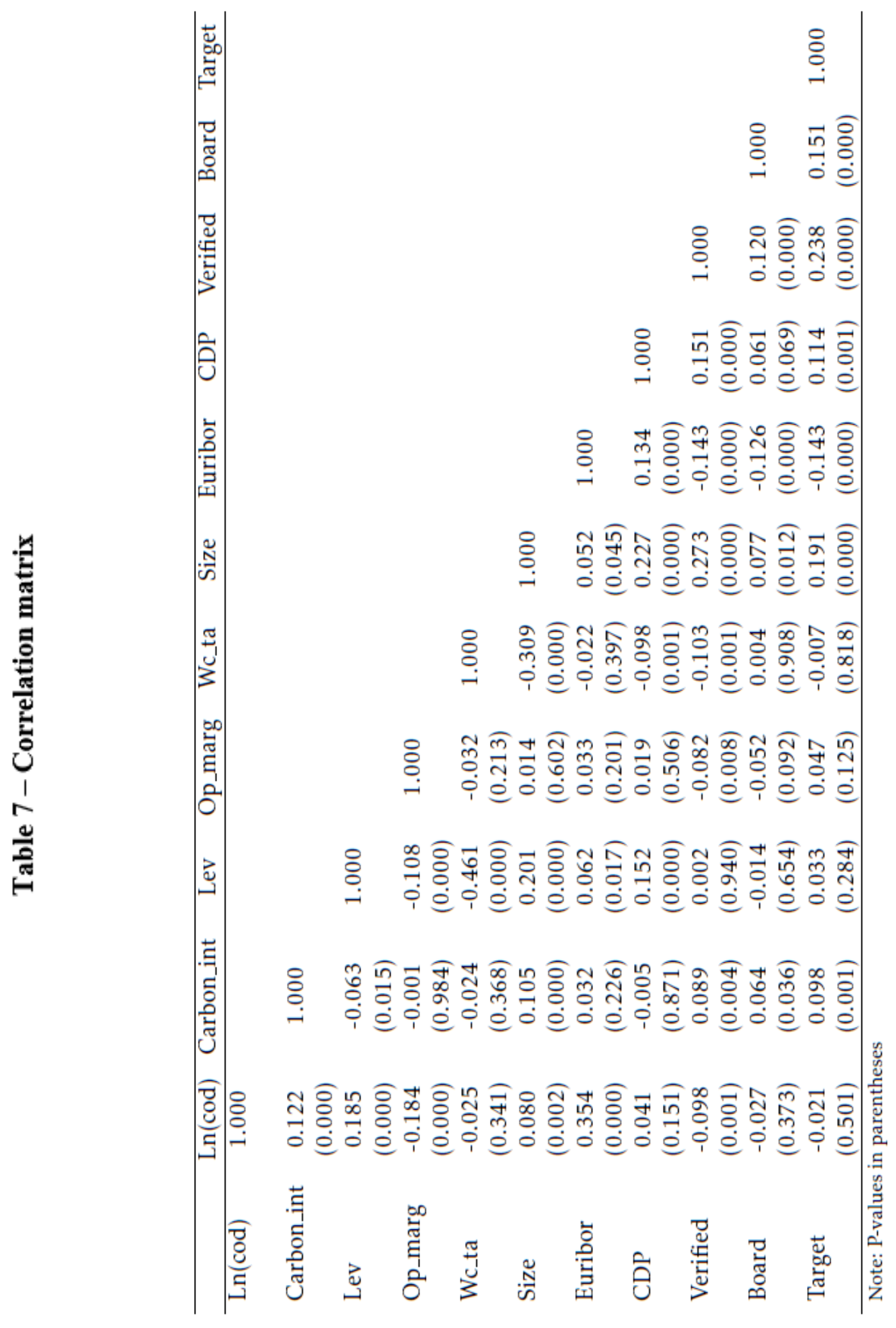

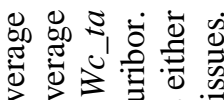

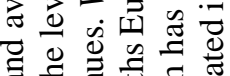

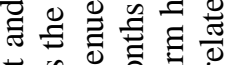

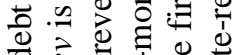
ช 0 ฮี

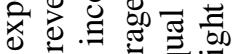

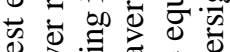

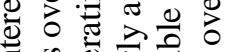

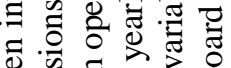
ब.

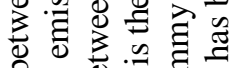
워용

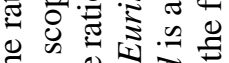
E की

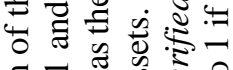

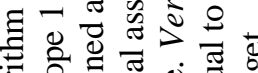

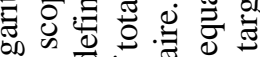

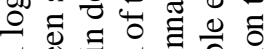

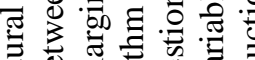

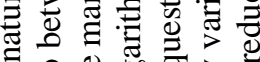

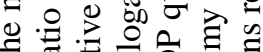

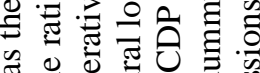

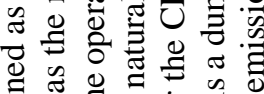
记

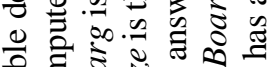

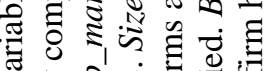
30 过目:

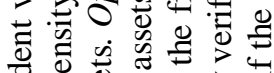

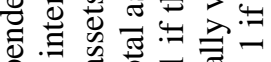
ํำ 记

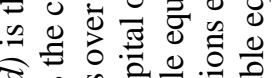
ชิ

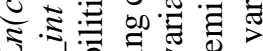

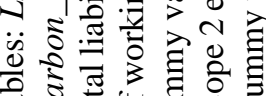
U。

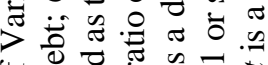
पे

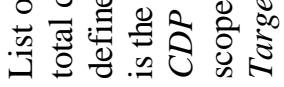


Table 8 - Regression results - Carbon risk

(1)

Full Sample Full Sample
(3)

(4)

\begin{tabular}{lcccc}
\hline Carbon_int & & $\mathbf{0 . 0 4 4 9}$ & $\mathbf{0 . 0 3 4 5}$ & $\mathbf{0 . 0 5 2 1}$ \\
Lev & & $\mathbf{( 0 . 0 0 1 )}$ & $\mathbf{( 0 . 0 9 3 )}$ & $(\mathbf{0 . 0 0 0})$ \\
& $\mathbf{0 . 3 6 0}$ & $\mathbf{0 . 4 1 8}$ & $\mathbf{0 . 3 0 9}$ & $\mathbf{0 . 5 6 3}$ \\
Op_marg & $\mathbf{( 0 . 0 0 4 )}$ & $\mathbf{( 0 . 0 0 1 )}$ & $\mathbf{( 0 . 0 3 2}$ & $\mathbf{( 0 . 0 0 0 )}$ \\
& $\mathbf{- 0 . 7 0 8}$ & $\mathbf{- 0 . 6 9 3}$ & $\mathbf{- 0 . 8 3 7}$ & $\mathbf{- 0 . 5 3 7}$ \\
Wc_ta & $\mathbf{( 0 . 0 0 0 )}$ & $\mathbf{( 0 . 0 0 0 )}$ & $\mathbf{( 0 . 0 0 0}$ & $\mathbf{( 0 . 0 0 2 )}$ \\
& $\mathbf{0 . 3 0 8}$ & $\mathbf{0 . 3 3 4}$ & $\mathbf{0 . 2 9 1}$ & 0.370 \\
Size & $\mathbf{( 0 . 0 4 0 )}$ & $\mathbf{( 0 . 0 2 1 )}$ & $\mathbf{( 0 . 0 8 4 )}$ & $(0.135)$ \\
& 0.0182 & 0.0162 & 0.00682 & 0.0257 \\
Constant & $(0.201)$ & $(0.250)$ & $(0.637)$ & $(0.144)$ \\
& $\mathbf{5 . 5 7 6}$ & $\mathbf{5 . 5 5 2}$ & $\mathbf{5 . 8 4 3}$ & $\mathbf{5 . 2 9 9}$ \\
Industry fixed effects & Yes & Yes & $\mathbf{( 0 . 0 0 0}$ & $(\mathbf{0 . 0 0 0})$ \\
Country fixed effects & Yes & Yes & Yes & Yes \\
Euribor & Yes & Yes & Yes & Yes \\
Observations & 1,469 & 1,469 & 886 & Yes \\
Adjusted R & 0.257 & 0.267 & 0.205 & 583 \\
\hline
\end{tabular}

$p$-values in parentheses

In bold variables of specific interest for the analysis. List of Variables: $\operatorname{Ln}(\operatorname{cod})$ is the dependent variable defined as the natural logarithm of the ratio between interest expense on debt and average total debt; Carbon_int is the carbon intensity computed as the ratio between scope 1 and scope 2 emissions over revenues. Lev is the leverage defined as total liabilities over total assets. $O p \_$marg is the operative margin defined as the ratio between operating income and revenues. $W c_{-} t a$ is the ratio of working capital over total assets. Size is the natural logarithm of total assets. Euribor is the yearly average of the 6-months Euribor. $C D P$ is a dummy variable equal to 1 if the firms answers the CDP questionnaire. Verified is a dummy variable equal to 1 if the firm has either scope 1 or scope 2 emissions externally verified. Board is a dummy variable equal to 1 if the firm has board oversight of climate-related issues. Target is a dummy variable equal to 1 if the firm has an emissions reduction target. Industry is the 2-digits ICB industry code.

Robust standard errors clustered by firm and year. 
Table 9 - Regression results - Post-Paris effect and High versus Low emitters

\begin{tabular}{|c|c|c|c|}
\hline & $\begin{array}{c}\text { (1) } \\
\text { Full Sample }\end{array}$ & $\begin{array}{c}(2) \\
\text { HE Group }\end{array}$ & $\begin{array}{c}\text { (3) } \\
\text { LE Group }\end{array}$ \\
\hline \multirow[t]{2}{*}{ Carbon_int } & 0.0270 & 0.0362 & -0.0211 \\
\hline & $(0.156)$ & $(0.049)$ & $(0.519)$ \\
\hline \multirow[t]{2}{*}{ Carbon_int x Post_2015 } & 0.0418 & 0.0182 & 0.103 \\
\hline & $(0.059)$ & $(0.433)$ & (0.018) \\
\hline \multirow[t]{2}{*}{ Post_2015 } & -0.149 & -0.142 & -0.144 \\
\hline & $(0.002)$ & $(0.005)$ & $(0.001)$ \\
\hline \multirow[t]{2}{*}{ Lev } & 0.386 & 0.224 & 0.463 \\
\hline & $(0.001)$ & $(0.185)$ & $(0.001)$ \\
\hline \multirow[t]{2}{*}{ Op_marg } & -0.712 & -0.737 & -0.668 \\
\hline & $(0.000)$ & $(0.000)$ & $(0.002)$ \\
\hline \multirow[t]{2}{*}{ Wc_ta } & 0.246 & -0.427 & 0.475 \\
\hline & $(0.078)$ & $(0.028)$ & $(0.007)$ \\
\hline \multirow[t]{2}{*}{ Size } & 0.0106 & 0.0115 & -0.00186 \\
\hline & $(0.423)$ & $(0.628)$ & $(0.934)$ \\
\hline \multirow[t]{2}{*}{ Constant } & 5.528 & 6.168 & 5.434 \\
\hline & $(0.000)$ & $(0.000)$ & $(0.000)$ \\
\hline Industry fixed effects & Yes & Yes & Yes \\
\hline Country fixed effects & Yes & Yes & Yes \\
\hline Euribor & Yes & Yes & Yes \\
\hline Observations & 1,469 & 599 & 870 \\
\hline Adjusted $\mathrm{R}^{2}$ & 0.335 & 0.361 & 0.353 \\
\hline
\end{tabular}

$p$-values in parentheses

In bold variables of specific interest for the analysis. List of Variables: $\operatorname{Ln}(\operatorname{cod})$ is the dependent variable defined as the natural logarithm of the ratio between interest expense on debt and average total debt; Carbon_int is the carbon intensity computed as the ratio between scope 1 and scope 2 emissions over revenues. Lev is the leverage defined as total liabilities over total assets. Op_marg is the operative margin defined as the ratio between operating income and revenues. $W c_{-} t a$ is the ratio of working capital over total assets. Size is the natural logarithm of total assets. Euribor is the yearly average of the 6-months Euribor. $C D P$ is a dummy variable equal to 1 if the firms answers the CDP questionnaire. Verified is a dummy variable equal to 1 if the firm has either scope 1 or scope 2 emissions externally verified. Board is a dummy variable equal to 1 if the firm has board oversight of climate-related issues. Target is a dummy variable equal to 1 if the firm has an emissions reduction target. Industry is the 6-digit ICB industry code.

Robust standard errors clustered by firm and year. 
Table 10 - Sample distribution by sector -Carbon intensity statistics

\begin{tabular}{lcccccc}
\hline & Median & Mean & Min & Max & Sd & $\mathrm{N}$. \\
\hline Electricity & 1.18 & 1.37 & 0.01 & 5.60 & 1.13 & 89 \\
Gas, Water and Multi-utilities & 0.94 & 1.23 & 0.22 & 3.62 & 1.02 & 61 \\
Travel and Leisure & 0.58 & 0.66 & 0.00 & 1.44 & 0.53 & 30 \\
Chemicals & 0.52 & 0.71 & 0.02 & 4.81 & 0.76 & 80 \\
Industrial Materials & 0.46 & 0.51 & 0.34 & 0.76 & 0.16 & 16 \\
Industrial Metals and Mining & 0.36 & 0.45 & 0.00 & 1.10 & 0.25 & 53 \\
Energy & 0.36 & 0.48 & 0.00 & 3.42 & 0.51 & 98 \\
General Industrials & 0.30 & 0.34 & 0.02 & 0.86 & 0.28 & 29 \\
Construction and Materials & 0.11 & 1.22 & 0.01 & 8.76 & 2.33 & 143 \\
Food Producers & 0.10 & 0.19 & 0.06 & 0.74 & 0.19 & 29 \\
Beverages & 0.07 & 0.06 & 0.00 & 0.12 & 0.04 & 33 \\
Automobiles and Parts & 0.06 & 0.07 & 0.00 & 0.19 & 0.04 & 59 \\
Health Care Providers & 0.05 & 0.04 & 0.03 & 0.05 & 0.01 & 8 \\
Electronic and Electrical Equipment & 0.04 & 0.05 & 0.02 & 0.15 & 0.03 & 42 \\
Pharmaceuticals and Biotechnology & 0.04 & 0.36 & 0.01 & 3.21 & 0.88 & 56 \\
Industrial Transportation & 0.04 & 0.16 & 0.00 & 7.28 & 0.73 & 98 \\
Personal Care, Drug and Grocery Stores & 0.04 & 0.04 & 0.00 & 0.10 & 0.02 & 48 \\
Household Goods and Home Construction & 0.04 & 0.04 & 0.01 & 0.05 & 0.01 & 11 \\
Telecommunications Service Providers & 0.04 & 0.04 & 0.00 & 0.18 & 0.03 & 110 \\
Retailers & 0.04 & 0.03 & 0.00 & 0.08 & 0.02 & 16 \\
Medical Equipment and Services & 0.03 & 0.12 & 0.01 & 0.72 & 0.22 & 20 \\
Aerospace and Defense & 0.02 & 0.03 & 0.01 & 0.14 & 0.03 & 38 \\
Industrial Engineering & 0.02 & 0.02 & 0.01 & 0.06 & 0.01 & 42 \\
Technology Hardware and Equipment & 0.02 & 0.07 & 0.01 & 0.38 & 0.10 & 32 \\
Telecommunications Equipment & 0.01 & 0.02 & 0.01 & 0.03 & 0.01 & 17 \\
Industrial Support Services & 0.01 & 0.02 & 0.00 & 0.03 & 0.01 & 37 \\
Software and Computer Services & 0.01 & 0.01 & 0.00 & 0.04 & 0.01 & 59 \\
Media & 0.01 & 0.02 & 0.00 & 0.12 & 0.02 & 79 \\
Leisure Goods & 0.01 & 0.01 & 0.01 & 0.01 & 0.00 & 8 \\
Personal Goods & 0.01 & 0.01 & 0.00 & 0.02 & 0.00 & 28 \\
Total & 0.06 & 0.41 & 0.00 & 8.76 & 1.00 & 1,469 \\
\hline & & & & & & \\
& & & & & \\
& & &
\end{tabular}


Table 11 - Regression results - The effect of disclosure: answering the CDP questionnaire

(1)

Full Sample
(2)

HE Group
(3)

LE Group
(4)

(5)

HE Group Pre- HE Group Post-

Paris Agreement Paris Agreement

\begin{tabular}{lccccc}
\hline Carbon_int & $\mathbf{0 . 0 9 2 0}$ & $\mathbf{0 . 0 6 9 2}$ & 0.0486 & -0.498 & $\mathbf{0 . 0 6 9 5}$ \\
& $\mathbf{( 0 . 0 0 0 )}$ & $\mathbf{( 0 . 0 0 0 )}$ & $(0.240)$ & $(0.253)$ & $(\mathbf{0 . 0 0 0 )}$ \\
Carbon_int x CDP & $\mathbf{- 0 . 0 5 8 2}$ & -0.0407 & 0.424 & 0.524 & -0.0479 \\
& $\mathbf{( 0 . 0 8 6 )}$ & $(0.128)$ & $(0.209)$ & $(0.230)$ & $(0.304)$ \\
CDP & 0.0192 & $\mathbf{- 0 . 1 9 0}$ & 0.0603 & -0.0943 & $\mathbf{- 0 . 3 1 9}$ \\
& $(0.686)$ & $\mathbf{( 0 . 0 3 4 )}$ & $(0.298)$ & $(0.405)$ & $\mathbf{( 0 . 0 0 0 )}$ \\
Lev & 0.491 & 0.187 & 0.583 & 0.0483 & 0.552 \\
& $(0.000)$ & $(0.337)$ & $(0.000)$ & $(0.814)$ & $(0.009)$ \\
Op_marg & -0.697 & -0.778 & -0.753 & -0.977 & -0.375 \\
& $(0.000)$ & $(0.000)$ & $(0.000)$ & $(0.000)$ & $(0.000)$ \\
Wc_ta & 0.249 & -0.476 & 0.539 & -0.347 & -0.343 \\
Size & $(0.013)$ & $(0.006)$ & $(0.000)$ & $(0.328)$ & $(0.280)$ \\
& 0.0236 & 0.0291 & 0.00624 & 0.00747 & 0.0693 \\
Constant & $(0.087)$ & $(0.242)$ & $(0.810)$ & $(0.804)$ & $(0.006)$ \\
& 5.102 & 5.939 & 5.015 & 6.363 & 5.199 \\
Industry fixed effects & $(0.000)$ & $(0.000)$ & $(0.000)$ & $(0.000)$ & $(0.000)$ \\
Country fixed effects & Yes & Yes & Yes & Yes & Yes \\
Euribor & Yes & Yes & Yes & Yes & Yes \\
Observations & 1,132 & Yes & Yes & Yes & Yes \\
Adjusted R ${ }^{2}$ & 0.389 & 0.417 & 658 & 281 & 193 \\
\hline
\end{tabular}

$p$-values in parentheses

In bold variables of specific interest for the analysis. List of Variables: $\operatorname{Ln}(\operatorname{cod})$ is the dependent variable defined as the natural logarithm of the ratio between interest expense on debt and average total debt; Carbon_int is the carbon intensity computed as the ratio between scope 1 and scope 2 emissions over revenues. Lev is the leverage defined as total liabilities over total assets. $O P_{-}$marg is the operative margin defined as the ratio between operating income and revenues. $W c_{-} t a$ is the ratio of working capital over total assets. Size is the natural logarithm of total assets. Euribor is the yearly average of the 6-months Euribor. CDP is a dummy variable equal to 1 if the firms answers the CDP questionnaire. Verified is a dummy variable equal to 1 if the firm has either scope 1 or scope 2 emissions externally verified. Board is a dummy variable equal to 1 if the firm has board oversight of climate-related issues. Target is a dummy variable equal to 1 if the firm has an emissions reduction target. Industry is the 6digit ICB industry code.

Robust standard errors clustered by firm. 
Table 12 - Regression results - Third-party verification of emissions, board oversight of climate issues, and emissions reduction target

\begin{tabular}{|c|c|c|c|c|c|}
\hline & $\begin{array}{c}\text { (1) } \\
\text { Full } \\
\text { Sample }\end{array}$ & $\begin{array}{c}(2) \\
\text { HE } \\
\text { Group } \\
\end{array}$ & $\begin{array}{c}(3) \\
\text { LE } \\
\text { Group } \\
\end{array}$ & $\begin{array}{c}\text { (4) } \\
\text { Pre-Paris } \\
\text { Agreement }\end{array}$ & $\begin{array}{c}\text { (5) } \\
\text { Post-Paris } \\
\text { Agreement }\end{array}$ \\
\hline \multicolumn{6}{|c|}{ Panel A: Third-party emissions verification } \\
\hline Carbon_int x Verified & $\begin{array}{l}-0.0337 \\
(0.194)\end{array}$ & $\begin{array}{l}-0.0151 \\
(0.617)\end{array}$ & $\begin{array}{c}0.974 \\
(0.081)\end{array}$ & $\begin{array}{l}-0.0292 \\
(0.331)\end{array}$ & $\begin{array}{l}-0.482 \\
(0.396)\end{array}$ \\
\hline Verified & $\begin{array}{r}-0.0719 \\
(0.311)\end{array}$ & $\begin{array}{r}-0.197 \\
(0.047)\end{array}$ & $\begin{array}{r}-0.0844 \\
(0.255)\end{array}$ & $\begin{array}{r}-0.126 \\
(0.032)\end{array}$ & $\begin{array}{c}0.118 \\
(0.364)\end{array}$ \\
\hline $\begin{array}{l}\text { Control variables, industry, and } \\
\text { country indicators }\end{array}$ & Yes & Yes & Yes & Yes & Yes \\
\hline Euribor & Yes & Yes & Yes & Yes & Yes \\
\hline Observations & 1,037 & 494 & 543 & 662 & 375 \\
\hline Adjusted $\mathrm{R}^{2}$ & 0.387 & 0.381 & 0.438 & 0.347 & 0.428 \\
\hline \multicolumn{6}{|c|}{ Panel B: Board oversight of climate-related issues } \\
\hline Carbon_int x Board & $\begin{array}{c}0.123 \\
(0.132)\end{array}$ & $\begin{array}{r}-0.0495 \\
(0.590)\end{array}$ & $\begin{array}{l}1.625 \\
(0.680)\end{array}$ & $\begin{array}{l}0.0678 \\
(0.251)\end{array}$ & $\begin{array}{c}0.514 \\
(0.052)\end{array}$ \\
\hline Board & $\begin{array}{r}-0.100 \\
(0.043)\end{array}$ & $\begin{array}{c}0.00328 \\
(0.985)\end{array}$ & $\begin{array}{l}-0.141 \\
(0.165)\end{array}$ & $\begin{array}{r}-0.0711 \\
(0.142)\end{array}$ & $\begin{array}{r}-0.0833 \\
(0.000)\end{array}$ \\
\hline $\begin{array}{l}\text { Control variables, industry, and } \\
\text { country indicators }\end{array}$ & Yes & Yes & Yes & Yes & Yes \\
\hline Euribor & Yes & Yes & Yes & Yes & Yes \\
\hline Observations & 1,052 & 496 & 556 & 677 & 375 \\
\hline Adjusted $\mathrm{R}^{2}$ & 0.385 & 0.371 & 0.433 & 0.333 & 0.438 \\
\hline \multicolumn{6}{|c|}{ Panel C: Emissions Reduction Target } \\
\hline Carbon_int x Target & $\begin{array}{l}0.0537 \\
(0.452)\end{array}$ & $\begin{array}{l}-0.00222 \\
(0.977)\end{array}$ & $\begin{array}{c}2.987 \\
(\mathbf{0 . 0 0 0 )}\end{array}$ & $\begin{array}{l}-0.0193 \\
(0.785)\end{array}$ & $\begin{array}{l}-0.226 \\
(0.399)\end{array}$ \\
\hline Target & $\begin{array}{r}-0.0364 \\
(0.517)\end{array}$ & $\begin{array}{l}-0.0161 \\
(0.841)\end{array}$ & $\begin{array}{r}-0.123 \\
(0.064)\end{array}$ & $\begin{array}{c}0.00683 \\
(0.905)\end{array}$ & $\begin{array}{r}-0.0724 \\
(0.483)\end{array}$ \\
\hline $\begin{array}{l}\text { Control variables, industry, and } \\
\text { country indicators }\end{array}$ & Yes & Yes & Yes & Yes & Yes \\
\hline Euribor & Yes & Yes & Yes & Yes & Yes \\
\hline Observations & 1,046 & 496 & 550 & 676 & 370 \\
\hline Adjusted $\mathrm{R}^{2}$ & 0.382 & 0.370 & 0.438 & 0.329 & 0.439 \\
\hline
\end{tabular}

p-values in parentheses

In bold variables of specific interest for the analysis. List of Variables: $\operatorname{Ln}(\operatorname{cod})$ is the dependent variable defined as the natural logarithm of the ratio between interest expense on debt and average total debt; Carbon_int is the carbon intensity computed as the ratio between scope 1 and scope 2 emissions over revenues. $L e v$ is the leverage defined as total liabilities over total assets. Op_marg is the operative margin defined as the ratio between operating income and revenues. Wc_ta is the ratio of working capital over total assets. Size is the natural logarithm of total assets. Euribor is the yearly average of the 6-months Euribor. $C D P$ is a dummy variable equal to 1 if the firms answers the CDP questionnaire. Verified is a dummy variable equal to 1 if the firm has either scope 1 or scope 2 emissions externally verified. Board is a dummy variable equal to 1 if the firm has board oversight of climate-related issues. Target is a dummy variable equal to 1 if the firm has an emissions reduction target. Industry is the 6-digit ICB industry code.

Robust standard errors clustered by firm and year. 